Dejana Pavlović ${ }^{1}$, Tijana Obradović ${ }^{2}$, Dragan Bjelica ${ }^{*}$

${ }^{1}$ Institute of Economic Sciences, Belgrade, Serbia

2 University of Belgrade, Faculty of Organizational Sciences, Serbia

\title{
Does Competitiveness Have Anything To Do With People?
}

DOI: 10.7595/management.fon.2018.0017

\begin{abstract}
Research Question: Improvement of the educational system facilitates access to labour market and affects stability as well as the competitiveness index. On the other hand, the country with a high score of GCl has a better educational system and more stable labour market. Motivation: Our goal was to investigate how important it is for a country to have educated people and how difficult it is to achieve a high rank in labour market efficiency without them. Results of the previous studies showed that higher education is connected with the labor market. According to this statement in the paper we analyzed two indicators, the Higher education and training and Labor market efficiency and their influence on the competitiveness score of the countries. Idea: The main idea was to analyze how higher education and training and labor market efficiency impact the competitiveness score of the country. Data: The data were collected from The Global Competitiveness Report 2015-2016. We analysed the influence of Higher Education and Training pillar and Labour Market Efficiency pillar on the overall rankings of 15 top competitiveness countries and 10 Balkan countries. Tools: In the paper we used correlation, clustering, and regression analyses. First, we compared the GCI 2015-2016 and the GCl 2014-2015. Second, we did cluster analysis between influential indicators in higher education and training pillar (pillar 5) as well as for Labour market efficiency pillar (pillar 7) to identify the difference between top 15 and the Balkan region countries. The regression analysis has been performed to determine the most influential indicators on $\mathrm{GCl}$ in pillar 5 and pillar 7 . Findings: The most important result is that the human resource development and market demands for competences affect the development of the country's economy. Contribution: Results may have important implications for labor market efficiency and strategic national labour market framework development.
\end{abstract}

Keywords: Higher education, Labour market, Human Resources, Global Competitiveness Index.

JEL Classification J08, J23, J24

\section{Introduction}

Recent evidence on the role of higher education and the labor market in promoting economic growth provides an explanation for the uncertain influence of human capital on competitiveness (Refrigeri and Aleandri, 2013). A key factor for gaining competitive advantage is applying innovative activity (Pavlovic, 2015) or in this case to invest in human capital. Constantini and Monni (2008) concluded that one of the most important aims for planning strategic policy is human, whereas an increase in human well-being is necessary to provide a sustainable path.

It becomes clear that the educational system, at least for the youth, must become a way to the labour market. Higher education is connected with the labor market and the most recent research investigated the influence of the demand for higher education on the labour market outcomes of skilled university graduates and unskilled-secondary school graduates (Bosio and Leonardi, 2010; Chevalier and Lindley, 2009; Walker and Zhu, 2008). Before the financial crisis, precisely in the period between 1997 and 2008, the proportion of university graduates increased by almost 60 percent in Italy, Spain, Greece, and Portugal, and by nearly 40 percent in the UK, France, and Norway. Accordinig to the results, about $4.8 \%$ of individuals with a tertiary degree and $12.6 \%$ of those lacking a secondary education were unemployed in 2011 (OECD, 2013). According to Tucker (2012), low-skilled persons are three times more likely not to find jobs than highly educated persons, and the poverty risk they face is twice as high in comparison with the medium-skilled ones. 
Furthermore, a large number of studies have discussed competitiveness with a focus on productivity, innovation, and skills (Fagerberg, 1996; Kazlauskaite and Buciuniene, 2008). Competitiveness is essential not only for business activities but also in national economies. The countries' competitiveness is often measured by GDP per capita or the trade performance. Fagerberg et al. (2007) showed that these two factors are closely related. The Institute for Management Development investigated the nations' competitiveness analysing four groups of factors that influence competitiveness, such as economic performance, government efficiency, business efficiency, and infrastructure (International Management Development Institute, 2001). Some of the existing studies emphasized the methodological transparency as a viable solution to problems caused by present aggregated indicators (Onsel et al., 2008). Fagerberg et al. (2007) studied the impact of technology, capacity, demand competitiveness for growth and development on the competitiveness. The results of research which is based on a sample of 90 countries on different levels of development during 19802000 showed that price was the least important factor.

The competitiveness of the EU regions includes several types of dynamic economies of agglomeration:

1. regions as places of production;

2. regions as sources of increasing returns;

3. regions as knowledge centres;

4. the new sources of competitive advantage relate to the construction of new forms of strategic, organizational, productive, and labour-related practices: the network firm (Foss, 2005; Josserand, 2004; Capello, 2007; Montfort, 2008)

According to Artto (1987), a nation's level of competitiveness is described as "the degree to which a nation can, under free and fair market conditions, produce goods and services that meet the test of international markets while simultaneously expanding the real incomes of its citizens." State level economies are compared to each other by measuring competitive performance and mounting competitive strategy (Lall, 2001).

The aim of this paper is to analyse the influence of Higher Education and Training pillar and Labour Market Efficiency pillar on the overall rankings of 15 top competitiveness countries (Switzerland, Singapore, the United States, Finland, Germany, Japan, Hong Kong S.A.R., the Netherlands, the United Kingdom, Sweden, Norway, the United Arab Emirates, Denmark, Taiwan, China and Canada) and 10 Balkan countries (Serbia, Croatia, Bulgaria, Romania, Greece, Albania, F.Y.R. of Macedonia, Montenegro, Slovenia, Turkey) (World Economic Forum, 2016). The topic is interesting because some EU countries are suffering from weak growth and the adverse impact of financial crisis. The same scenario is anticipated in Non-EU Balkan Countries. The main research questions are: Does the improvement of educational system facilitate access to labour market and affect the stability? Will it affect the competitiveness index?; Does the country with a high score of $\mathrm{GCl}$ have a better educational system and more stable labour market?

Considering the national competitiveness worldwide, there is no doubt that the globally accepted score is given by the World Economic Forum, which has been traditionally organized in Davos for 35 years now. The Global Competitiveness Index ${ }^{1}(\mathrm{GCl})$ was introduced by the World Economic Forum in 2004, to measure national competitiveness. The role of the competitiveness index is to rank countries according to the selected criteria and to measure national competitive ability (Lall, 2001). The rank of a country's competitiveness is useful and valuable for investors, policy makers and politicians who want to improve the country's position at the world level.

The paper consists of the first part - the introduction presenting the subject of the research and objective as well as the research review, which provides the literature review of previous research on the topic of the impact of Human Resources on the competitiveness of companies, regions and countries. The second part of the paper presents a methodological framework and the research results. And finally, the last part provides the conclusion and discussion, as follows.

\section{Research Overview}

From the twentieth century onwards, human capital, which includes knowledge, skills and abilities of an individual, has become a key determinant of economic growth and development. Investment in human capital, especially in education, whereby a measurable component in defining human capital, will certainly contribute to the labour market stability. The results of the research conducted by Psacharopoulos and Patrinos (2004) implied that highly educated people have better salaries and position in comparison with less educated people. On the other hand, Spence's screening hypothesis and the Job competition theory emerged as criticism of this theory. Spence (1973) believes that an educated employee with a degree proves he/she can work, which in this case is a ticket to the labour market. The problem with employing young peo- 
ple is that companies seek to hire the best workers with work experience. According to authors Refrigeri and Aleandri (2013), the "employer has to bear in mind that the human capital of an individual must be increasingly made up of knowledge and skills acquired at school in addition to those acquired from work experience ".

Highly-educated people have more advantages than people with low education. They acquire fundamental abilities to learn about markets (Shane and Venkatarama, 2000); they are better organized and they have a better ability to solve issues and make a successful decision (Ucbasaran et al., 2008). Human capital and training at work have a crucial role for the company's development. Formal education allows an individual to expand learning attitudes and to gain organizational skills which can be useful for the development of the business (Shane and Venkatarama, 2000).

The evidence for the importance of knowledge management is considerably more present among the researchers. Holsapple and Singh (2001) advanced a model that identifies and characterizes Knowledge Management activities within an organization as an important factor to enhance its competitiveness.

The results of the research in the field of the role of human capital in developing countries imply that the central part of strategy of most organizations should be improvement in schooling attainment (Hanushek, 2013). Zinnes et al. (2001) observed carefully the countries in transition and successfully devised an indicator for the current level of international competitiveness. This indicator is, according to them, very useful as it allows for policy makers to identify areas where their countries are left behind the other countries. Additionally, the previously mentioned indicator is also compatible with the Global Competitiveness Report series categories. Concerning the revolutionary changes in transition economies, so far, it has been difficult to propose a uniform model of economic competitiveness (Hazakis, 2011).

A certain number of researchers analyzed how to improve the competitiveness of the countries with results obtained from the Global Competitiveness Report. Cirstea (2014) investigated competitiveness in tourism and travel industry among fifteen most development countries in the world according to the Global Competitiveness Report 2011-2012 of the World Economic Forum. These authors concluded that these countries were not a homogenous group, and that there were some differences among them. Wu et al. (2012) came to results which were useful for policy makers in their attempts to understand the nature of a destinations' competitive standing. The researchers used three indicators and fourteen pillars of travel and tourism competitiveness index explaining how pillars affect the overall rankings. A certain group of authors was involved in determining the model of competitiveness that countries use for improvement of human development (Ulengin et al. 2011). Additionally, the results of DEA indicated that in the countries such as China, Mexico, Brazil, India, Indonesia, Russia, and Turkey, the DEA values are very low. These countries used improvements regarding competitiveness but did not experience corresponding success in raising the levels of human development.

Policy makers use the results presented by the Global Competitiveness Report to make a better national strategy and to identify obstacles to improving competitiveness. Some of the strategies are related to youth unemployment reduction and change of educational system, as well as crucial problems in the world.

Table 1: Previous research in the field of competitiveness

\begin{tabular}{|c|c|c|}
\hline $\begin{array}{c}\text { Author's name and } \\
\text { year of publishing }\end{array}$ & Title of the paper & Methods \\
\hline Cirstea (2014) & $\begin{array}{c}\text { Travel and Tourism competitiveness: a study } \\
\text { of world's top economic competitive countries }\end{array}$ & $\begin{array}{c}\text { Pearson correlation } \\
\text { Linear correlation }\end{array}$ \\
\hline Wu et al. (2012) & $\begin{array}{c}\text { The Data Envelopment } \\
\text { (DEA) } \\
\text { Critiquing the World Economic Forum's } \\
\text { concept of destination competitiveness: A } \\
\text { further analysis }\end{array}$ & $\begin{array}{c}\text { The Bayesian Network (BN) } \\
\text { classifiers }\end{array}$ \\
\hline Ulengin et al. (2011) & $\begin{array}{c}\text { The Competitiveness of Nations and } \\
\text { implications for human development }\end{array}$ & $\begin{array}{c}\text { The Partial Least Squares (PLS) } \\
\text { path modelling }\end{array}$ \\
\hline Lall (2001) & $\begin{array}{c}\text { DEA } \\
\text { Competitiveness Indices and Developing } \\
\text { Countries: An Economic Evaluation of the } \\
\text { Global Competitiveness Report }\end{array}$ & $\begin{array}{c}\text { Competitive rankings by } \\
\text { International Institute for } \\
\text { Management Development and } \\
\text { World Economic Forum for 2000 }\end{array}$ \\
\hline
\end{tabular}

Source: Author's' literature review 


\section{Methodology}

\subsection{Global Competitiveness Index}

Even though the world competitiveness index is of great importance for ranking national economies and it significantly influences policy makers in strategy making processes, it has been criticized in recent years. According to Lall (2001), who analysed competitiveness index contained in the Global Competitiveness Report 2000 of the World Economic Forum, there are certain shortcomings in methodologies. First of all, the data have not been collected rigorously. About $90 \%$ respondents come from the private sector. Many qualitative measures are vague, redundant and wrong (Lall, 2001). These were some of the shortcomings for the Global Report 2000, but in 2004 the Global Competitiveness Index was designed for the first time. Three principles that the index is based on were presented in the Global Competitiveness Report 2005 (World Economic Forum, 2005):

1. Competitiveness of Nations was shown using the twelve pillars. Each of the pillars shows a different weight for each stage of development.

2. The first stage also called a factor-driven stage, is when companies compete on price and take advantage of cheap labour or unprocessed natural resources. The second stage, an efficiency-driven stage, is when efficient production becomes the main source of competitiveness. Countries with developed economies create the innovation-driven stage. They must produce innovative products and practices using the most advanced methods of production and organization. Stages are introduced because of some less developed countries. The first stage is allocated to the least developed countries, and to improve their competitiveness, the same strategy does not apply in the same manner as in case of developed countries. Therefore, the strategy implemented by Ghana is entirely different from that implemented by France.

3. National economies move from one stage to the next (World Economic Forum, 2005).

Based on the responses in the survey², which is used for creating a database for making $\mathrm{GCl}$ (Global Competitiveness Index), more than 14000 business leaders from 144 countries offered their opinions and answered the questions with the score from 1 to 7 , however, in some cases there there were exceptions where there wer indicators that were not derived and in case of the survey, such as indicator 7.4 for example ${ }^{3}$. This indicator estimates the cost of notice requirements, severance payments, and penalties due when terminating a redundant worker, expressed in weekly wages (World Economic Forum, 2015). In that way, we normalized the database. The variables of $\mathrm{GCl}$ which were crucial for our research are variables of pillars 5 and 7 which are listed in Table 2.

Table 2: $5^{\text {th }}$ and $7^{\text {th }}$ pillar indicators

\begin{tabular}{|l|l|}
\hline 5th pillar: Higher education and training & 7th pillar: Labour market efficiency \\
\hline 5.1. Secondary education enrollment & 7.1. Cooperation in labour-employer relations \\
\hline 5.2. Tertiary education enrollment & 7.2. Flexibility of wage determination \\
\hline 5.3. Quality of the education system & 7.3. Hiring and firing practices \\
\hline 5.4. Quality of maths and science education & 7.4. Redundancy costs, weeks of salary \\
\hline 5.5. Quality of management schools & 7.5. Effect of taxation on incentives to work \\
\hline 5.6. Internet access in schools & 7.6. Pay and productivity \\
\hline 5.7. Availability of specialized training services & 7.7. Reliance on professional management \\
\hline 5.8. Extent of staff training & 7.8. Country capacity to retain talent \\
\hline & 7.9. Country capacity to attract talent \\
\hline & 7.10. Women in labour force, ratio to men \\
\hline
\end{tabular}

\subsection{Multivariate analysis}

The analysis has been prepared using statistical software Rapid Miner for data processing. The Cluster analysis is used to group objects into several segments. In this paper, we used the clustering method to divide countries into $k$ groups so that each group is homogeneous with characteristics based on similarities of differences. The groups are not pre-defined, and the grouping is performed based on the similarities found. This method has become very popular among researchers and applied in different business environments. In our research countries are organized using the method of clustering for 25 countries, as well as the top 15 most competitive countries, and particularly for the Balkan countries.

The database comprises input variables, in this case, represented by pillars and 25 countries. Data mining is a discipline that has become extremely popular among researchers and decision-makers. Data mining 
model such as classification, regression, time series, clustering, association analysis and sequence discovery can be useful to solve problems and to make sound decisions.

Also, the paper includes the correlation and regression methods in order to estimate the relationships among variables, and the prediction of the results (North, 2012). Regression analysis should give the answer to the following questions:

1. Does a set of predictor variables (higher education and training variables, and labour market efficiency variables) predict a dependent variable (Global Competitiveness Index)?

2. Which variables in particular are significant predictors of the Global Competitiveness Index?

\subsection{Research plan}

Based on the averages for 2015 the column score 2015 in Table 3 shows a country's score in the 12 pillars. Also, the rank change exemplifies the change of position between rank 2015 and rank 2014 in relation to the total score. Results are prepared in four sequences:

1. Comparison of the $\mathrm{GCl} 2015-2016$ and the $\mathrm{GCl} 2014-2015$

2. Correlation analysis between influential indicators in Higher education and training pillar (pillar 5) and Labour market efficiency pillar (pillar 7)

3. Cluster analysis between influential indicators in higher education and training pillar (pillar 5) and Labour market efficiency pillar (pillar 7) to identify differences between top 15 and Balkan region countries

4. Perform regression analysis to determine the most influential indicators on $\mathrm{GCl}$ in pillar 5 and pillar 7 .

\section{Research Results}

\subsection{Comparison of scores and ranks in $\mathrm{GCl}$}

The research involved 15 top countries in order to determine similarities in trend development in the Balkan countries. In addition, some of the Balkan countries (such as Serbia, Bosnia and Herzegovina, Macedonia, Montenegro) are in the EU developing process and becoming a EU applicant country involve accomplishment and improvement regarding the list of conditions in higher education and labour market efficiency.

Table 3 shows that for the five most competitive countries such as Switzerland, Singapore, the United States, Japan and Hong Kong rank has not changed for three years, according to the Global Competitiveness Report. It can be seen that Switzerland remains on the position of the world leader according to this Report. There is no doubt that Switzerland has one of the best economies with the score for higher education and training 6 out of 7 and, in case of labour market and efficiency, of 5.8 out of 7 . Results showed that Sweden decreased from the $6^{\text {th }}$ place in 2013 to the $10^{\text {th }}$ in 2014 and, according to the Global Competitiveness Report 2015-2016, Sweden is in the $9^{\text {th }}$ place, and now holds the UK's last year's position. Canada, similarly to Germany, has improved its position by one rank between 2013 and 2015. Having in mind the negative consequences of the global crisis, the improvement of the Balkan countries is small or non-existing at all in comparison with the previous year.

Analysing the GCI mark, shown through rank and score, the Republic of Serbia had seen a decrease in the rank - from 2014 when Serbia was ranked the 93, it has moved to position 94 in 2015. On the other hand, the situation is different in Romania, which changed the rank from 59 to 53 . The other Balkan countries have remained at the same GCl level as last year, namely, Croatia, Bulgaria, and Greece.

Table 3: Comparison of scores and ranks in GCl between 2014/2015 among top 15 developed and Balkan countries

\begin{tabular}{|c|c|c|c|c|c|c|}
\hline & & SCORE 2015 & RANK 2015 & RANK 2014 & RANK 2013 & $\begin{array}{c}\text { RANK CHANGE } \\
\text { (2015 vs 2014) }\end{array}$ \\
\hline TOP & Switzerland & 5.76 & 1 & 1 & 1 & - \\
\hline TOP & Singapore & 5.68 & 2 & 2 & 2 & - \\
\hline TOP & United States & 5.61 & 3 & 3 & 3 & - \\
\hline TOP & Finland & 5.45 & 8 & 4 & 4 & -4 \\
\hline TOP & Germany & 5.53 & 4 & 5 & 4 & 1 \\
\hline TOP & Japan & 5.47 & 6 & 6 & 6 & - \\
\hline TOP & Hong Kong SAR & 5.46 & 7 & 7 & 7 & - \\
\hline
\end{tabular}




\begin{tabular}{llccccc}
\hline & & SCORE 2015 & RANK 2015 & RANK 2014 & RANK 2013 & $\begin{array}{c}\text { RANK CHANGE } \\
\text { (2015 vs 2014) }\end{array}$ \\
\hline TOP & Netherlands & 5.5 & 5 & 8 & 8 & 3 \\
TOP & United Kingdom & 5.43 & 10 & 9 & 10 & -1 \\
TOP & Sweden & 5.43 & 9 & 10 & 6 & 1 \\
TOP & Norway & 5.41 & 11 & 11 & 11 & - \\
TOP & Qatar & 5.3 & 14 & 13 & 13 & -1 \\
TOP & Denmark & 5.33 & 12 & 13 & 15 & -1 \\
TOP & Taiwan. China & 5.28 & 15 & 14 & 12 & -1 \\
TOP & Canada & 5.31 & 13 & 15 & 14 & 2 \\
Balkan & Serbia & 3.89 & 94 & 94 & 101 & - \\
Balkan & Croatia & 4.07 & 77 & 77 & 75 & - \\
Balkan & Bulgaria & 4.32 & 54 & 54 & 57 & - \\
Balkan & Romania & 4.32 & 53 & 59 & 76 & - \\
Balkan & Greece & 4.02 & 81 & 81 & 91 & - \\
Balkan & Albania & 3.93 & 93 & 97 & 95 & 3 \\
Balkan & Macedonia. FYR & 4.28 & 60 & 63 & 73 & -3 \\
Balkan & Montenegro & 4.2 & 70 & 67 & 67 & 11 \\
Balkan & Slovenia & 4.28 & 59 & 70 & 62 & -6 \\
Balkan & Turkey & 4.37 & 51 & 45 & 44 & \\
\hline
\end{tabular}

Source: The Global Competitiveness Report 2016, WEF

\subsection{Correlation analysis}

In the paper, we aim to present the correlation between two pillars and the $\mathrm{GCl}$ score using Pearson correlation coefficient, which is a measure of the strength of a linear association between two variables (Cohen et al., 2013). In our example, the results of Pearson Correlation Coefficents are presented in Table 4-6. The degree of correlation for pillars covered by our study indicates $r=0.78$ that represents a direct correlation between Higher education and training and Labour market efficiency (Table 4). On the other hand, there is noticeable higher level of correlation between pillars and GCl.

Table 4: Pearson correlation coefficient between 5th and 7th pillars and $\mathrm{GCl}$

\begin{tabular}{lccc}
\hline \multicolumn{1}{c}{ Pillar } & $\mathbf{1}$ & $\mathbf{2}$ & $\mathbf{3}$ \\
\hline 1. Higher education and training & 1.00 & 0.78 & 0.892 \\
2. Labour market efficiency & & 1.00 & 0.821 \\
3. GCl & & & 1.00 \\
\hline
\end{tabular}

Pearson correlations have statistical significance at the level 0.01

In Table 5, the highest correlation is found between 5.7 in Availability of research and training services and 5.8 in Extending of staff training as well between 5.3 in Quality of the education system and 5.8 in Extending of staff training.

Table 5: Pearson correlation coefficient between the variables of the pillar Higher education and training

\begin{tabular}{ccccccccc}
\hline & $\mathbf{5 . 1}$ & $\mathbf{5 . 2}$ & $\mathbf{5 . 3}$ & $\mathbf{5 . 4}$ & $\mathbf{5 . 5}$ & $\mathbf{5 . 6}$ & $\mathbf{5 . 7}$ & $\mathbf{5 . 8}$ \\
\hline $\mathbf{5 . 1}$ & 1.00 & 0.51 & 0.38 & 0.33 & 0.43 & 0.44 & 0.48 & 0.38 \\
$\mathbf{5 . 2}$ & & 1.00 & 0.06 & 0.16 & 0.19 & 0.24 & 0.23 & 0.17 \\
$\mathbf{5 . 3}$ & & & 1.00 & 0.72 & 0.88 & 0.73 & 0.83 & 0.89 \\
$\mathbf{5 . 4}$ & & & & 1.00 & 0.60 & 0.50 & 0.56 & 0.52 \\
$\mathbf{5 . 5}$ & & & & & 1.00 & 0.79 & 0.85 & 0.80 \\
$\mathbf{5 . 6}$ & & & & & & 1.00 & 0.78 & 0.70 \\
$\mathbf{5 . 7}$ & & & & & & & 1.00 & 0.89 \\
$\mathbf{5 . 8}$ & & & & & & & & 1.00 \\
\hline
\end{tabular}

Pearson correlations have a statistical significance at the level 0.01

In Table 6, the highest correlation is found between 7.8, Country Capacity to retain talent and 7.7, Reliance on professional management. A negative correlation is immanent to Redundancy costs, weeks of salary with other variables, and for Women in labour force, ratio to men in most comparisons. 
Table 6: Pearson correlation coefficient between the variables of the pillar Labour Market Efficiency

\begin{tabular}{ccccccccccc}
\hline & $\mathbf{7 . 1}$ & $\mathbf{7 . 2}$ & $\mathbf{7 . 3}$ & $\mathbf{7 . 4}$ & $\mathbf{7 . 5}$ & $\mathbf{7 . 6}$ & $\mathbf{7 . 7}$ & $\mathbf{7 . 8}$ & $\mathbf{7 . 9}$ & $\mathbf{7 . 1 0}$ \\
\hline $\mathbf{7 . 1}$ & 1.00 & 0.00 & 0.46 & -0.23 & 0.68 & 0.57 & 0.89 & 0.83 & 0.80 & 0.22 \\
$\mathbf{7 . 2}$ & & 1.00 & 0.54 & -0.26 & 0.39 & 0.64 & -0.16 & -0.10 & 0.16 & -0.47 \\
$\mathbf{7 . 3}$ & & & 1.00 & -0.17 & 0.64 & 0.74 & 0.30 & 0.39 & 0.59 & -0.20 \\
$\mathbf{7 . 4}$ & & & & 1.00 & -0.31 & -0.23 & -0.17 & -0.20 & -0.27 & -0.31 \\
$\mathbf{7 . 5}$ & & & & & 1.00 & 0.80 & 0.53 & 0.68 & 0.76 & -0.21 \\
$\mathbf{7 . 6}$ & & & & & & 1.00 & 0.39 & 0.50 & 0.63 & -0.23 \\
$\mathbf{7 . 7}$ & & & & & & & 1.00 & 0.91 & 0.83 & 0.36 \\
$\mathbf{7 . 8}$ & & & & & & & & 1.00 & 0.92 & 0.23 \\
$\mathbf{7 . 9}$ & & & & & & & & & 1.00 & 0.14 \\
$\mathbf{7 . 1 0}$ & & & & & & & & & & 1.00 \\
\hline
\end{tabular}

Pearson correlations have statistical significance at the level 0.01

\subsection{Cluster analysis}

The silhouette score is the highest for three clusters, and in the analysis for Pillar 5 involves three groups (Figure 1).

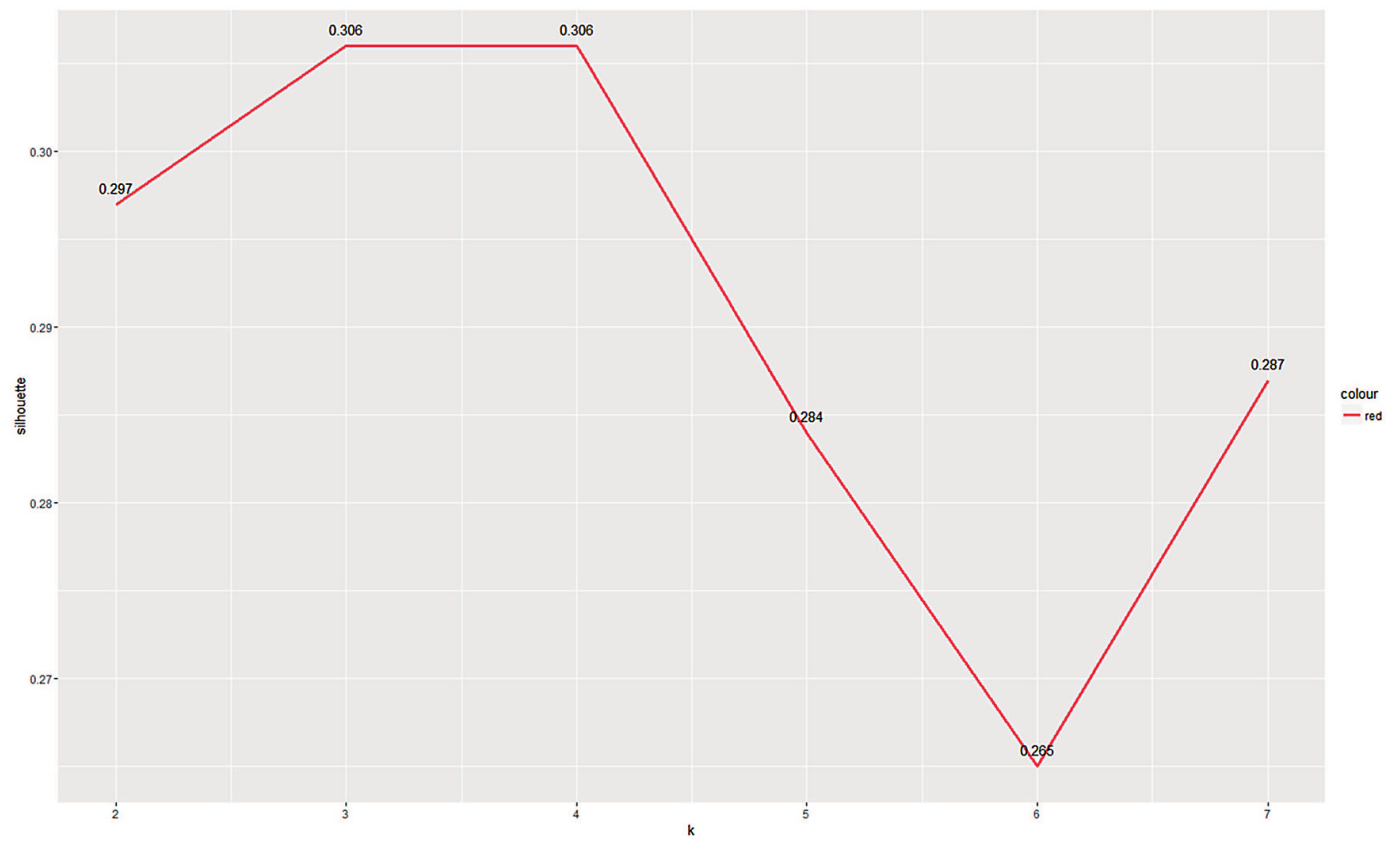

Figure 1: Value of silhouette score for $\mathrm{k}$ ranging from 2 to 7 for clustering based on variables of pillar 5

Within the analysis of the cluster of Pillar 5 , the following countries belong to the clusters listed (Figure 2):

- Cluster 1: Switzerland, Singapore, the Netherlands, Finland

- Cluster 2: the United States, Germany, Japan, Hong Kong S.A.R., the United Kingdom, Sweden, Norway, the United Arab Emirates, Denmark, Taiwan. China, Canada

- Cluster 3: Romania, Serbia, Croatia, Bulgaria, Greece, Albania, F.Y.R. of Macedonia, Montenegro, Slovenia, Turkey 


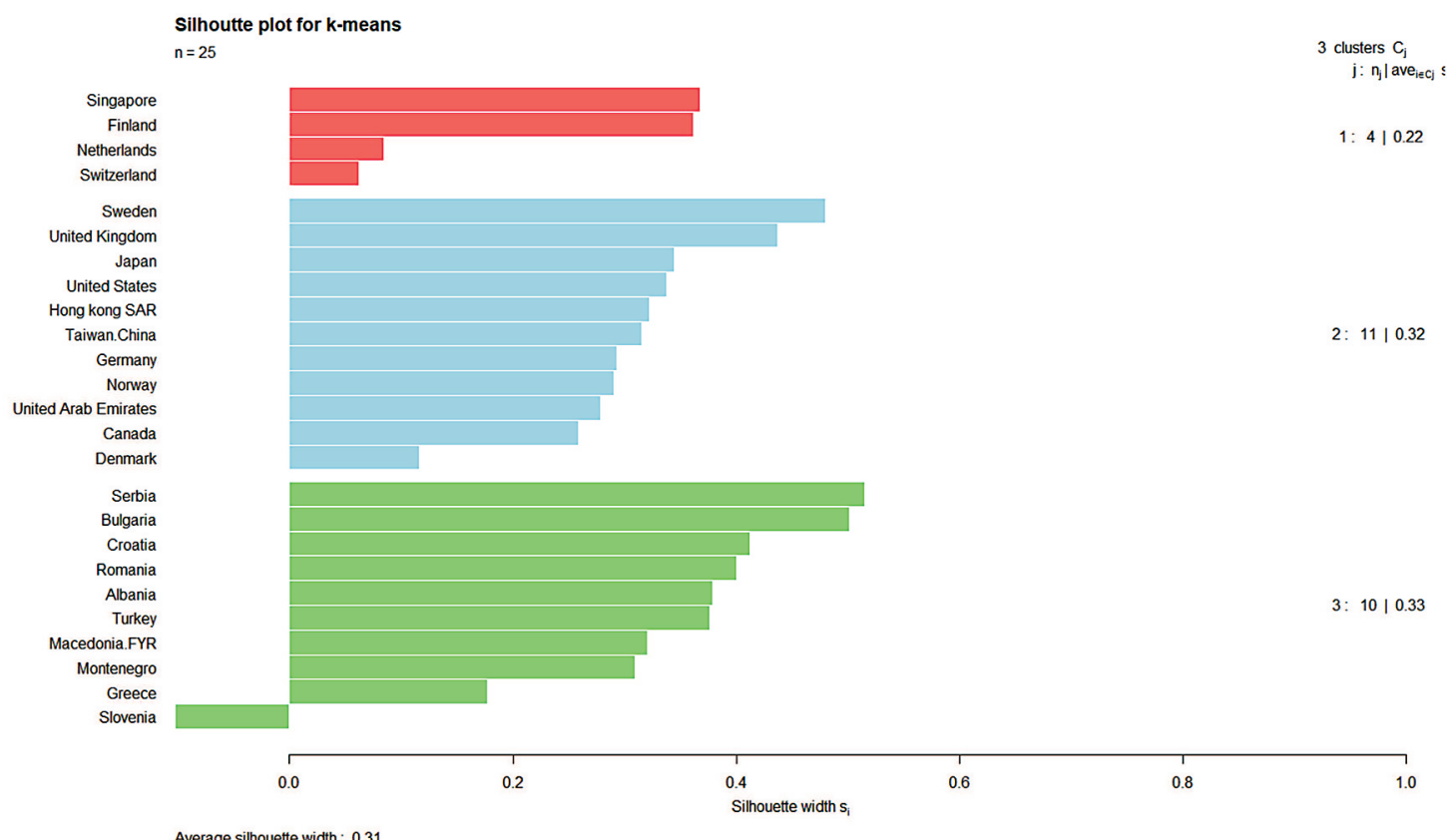

Figure 2: Silhouette plot for pillar 5

Cluster 1 consists of the top 4 countries, that in relation to Cluster 2 have a significantly higher value, from 5.1 - 5.5. On the other hand, in relation to Cluster 3 (which represents Balkan countries), the values are significantly higher, from 5.1-5.7. Comparing Cluster 2 and Cluster 3 , there is a noticeable higher value within the cluster 3 for 5.4, while values are lower for the other components (Figure 3). The silhouette score shows that Slovenia inclines to the other cluster.

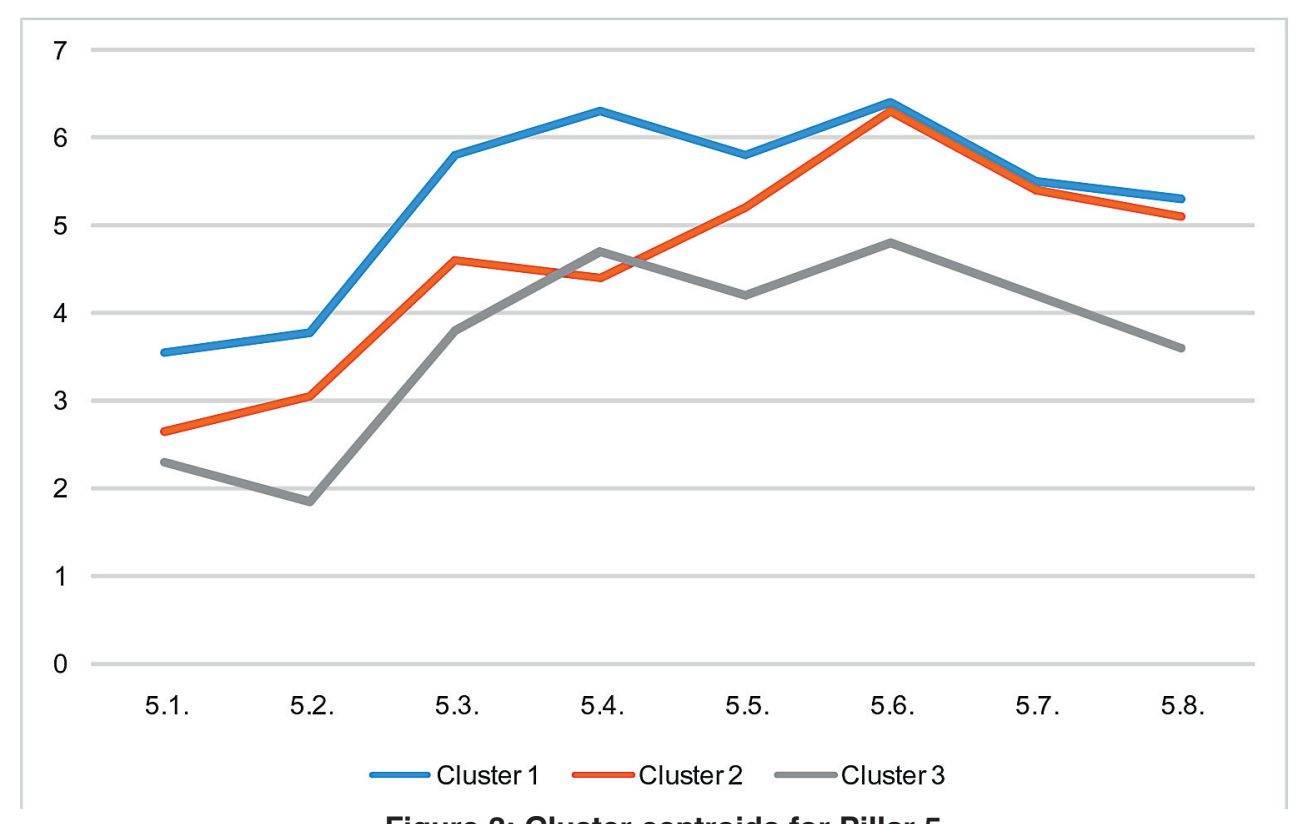

Figure 3: Cluster centroids for Pillar 5

The silhouette score is the highest for three clusters, and therefor the analysis for Pillar 7 involves three groups (Figure 4). 


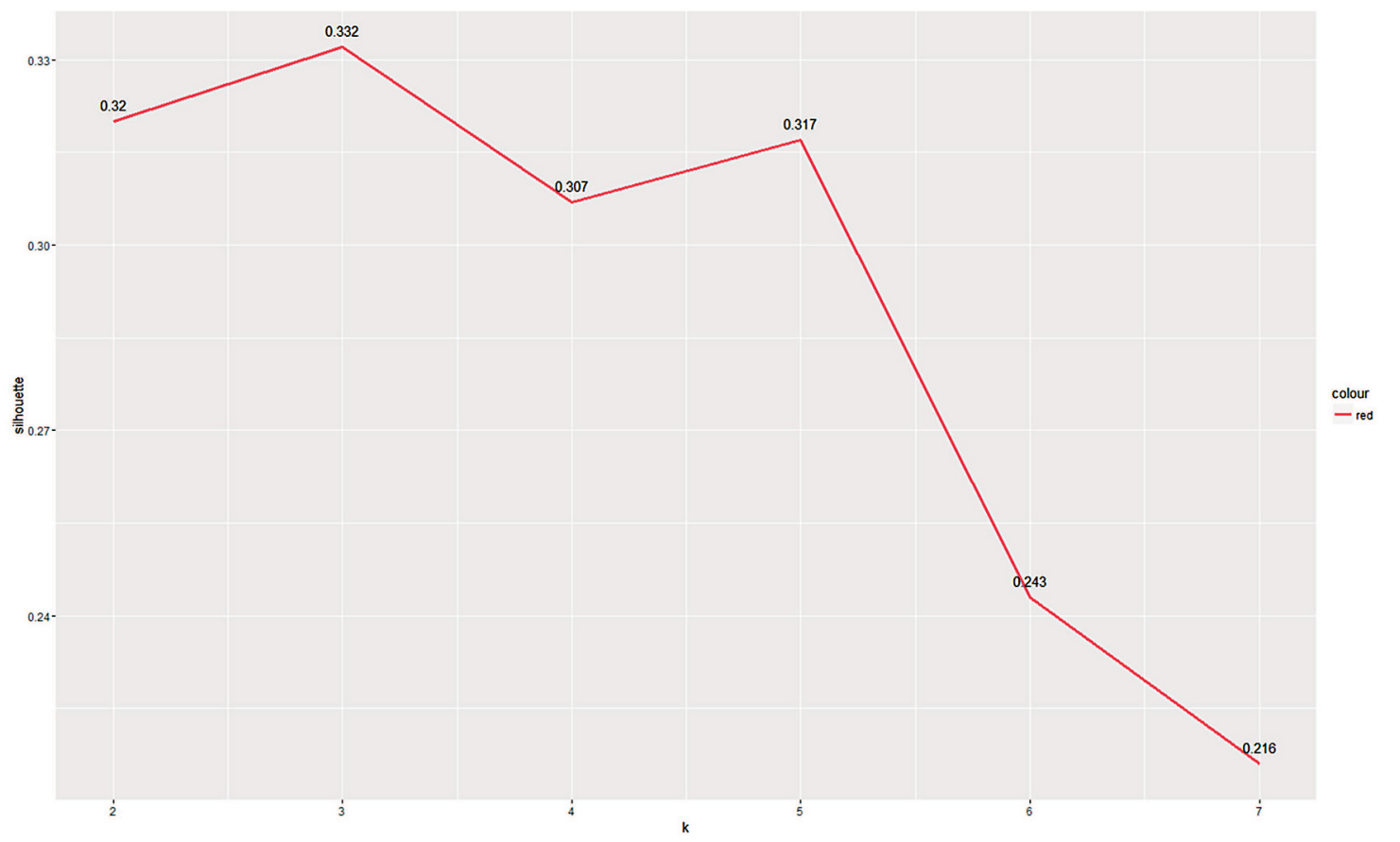

Figure 4: Value of silhouette score for k ranging from 2 to 7 for clustering based on variables of pillar 7

Within the cluster analysis of the Pillar 7, the following countries belong to the clusters listed (Figure 5):

- Cluster 1: Hong Kong, the UK, UAE, Switzerland, Singapore, the USA, Canada, Taiwan, Japan

- Cluster 2: Finland, Germany, the Netherlands, Sweden, Norway, Denmark

- Cluster 3: Serbia, Croatia, Bulgaria, Romania, Greece, Albania, Macedonia, Montenegro, Slovenia, Turkey

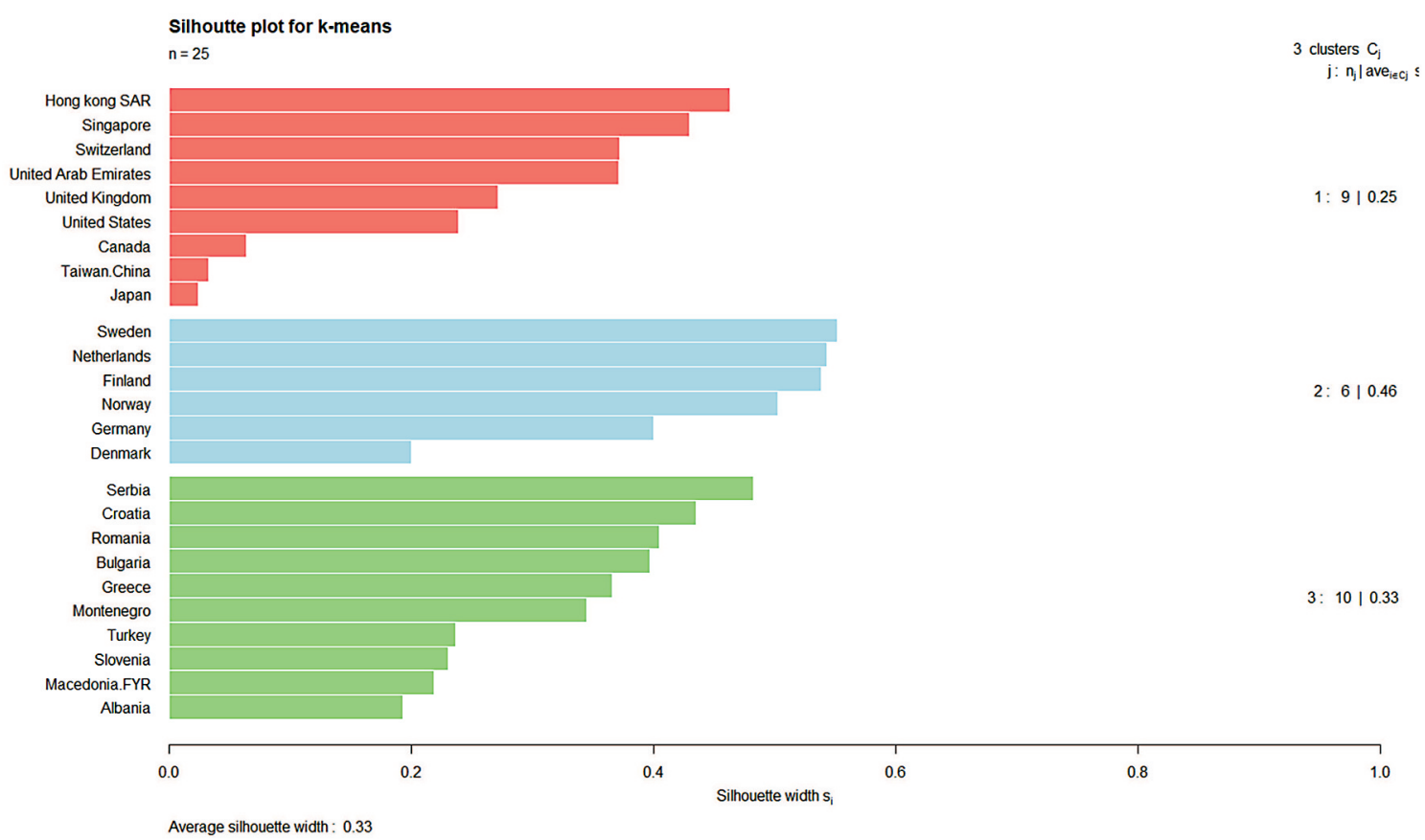

Figure 5: Silhouette plot for pillar 7

Cluster 1 has a lower value as compared to the cluster 2 and cluster 3 for component 7.4, and higher values for 7.2, 7.3.and 7.6. On the other hand, Cluster 2, in relation to Cluster 1 and cluster 3 , has a higher value for 7.1, 7.4. and 7.10, where Cluster 3, in comparison with Cluster 2, has a higher score for 7.2. and 7.6 (Figure 6). 


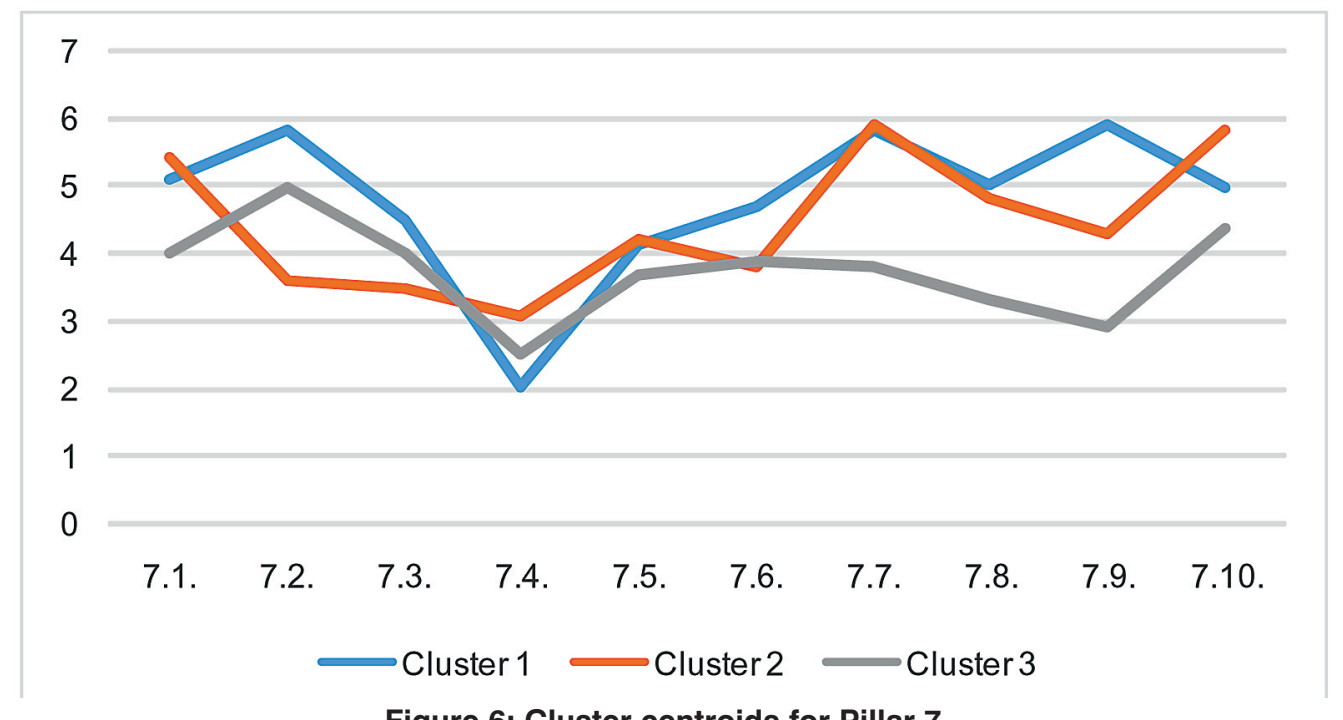

Figure 6: Cluster centroids for Pillar 7

\subsection{Linear regression analysis}

A multiple linear regression was calculated to analyze the best predictors of $\mathrm{GCl}$. The results of the regression model show that indicators of the Higher education and training, such as 5.1., Secondary education enrollment, 5.2., Tertiary education enrollment, 5.5., Quality of management schools, 5.6, Internet access in schools, are best predictors in this pillar. On the other hand, the best predictors of GCl in Labour Market Efficiency pillar are: 7.4., Redundancy costs, weeks of salary, 7.8., Country capacity to retain talent and 7.10., Women in labour force, ratio to men. Adjusted $\mathrm{R}^{2}$ indicates that $35 \%$ of the model explains all the variability of the responses around its mean.

Table 7. Best predictors' analysis of $\mathrm{GCl}$ for pillar 5 and 7 using linear regression analysis

\begin{tabular}{lcccccc}
\hline & Coefficient & Std. error & $\begin{array}{c}\text { Std. } \\
\text { coefficient }\end{array}$ & Tolerance & t-stat & p-value \\
\hline 5.1. & 0.28 & 0.10 & 0.48 & 0.83 & 2.83 & $0.02^{\star}$ \\
5.2. & -0.22 & 0.08 & -0.36 & 0.93 & -2.72 & $0.03^{*}$ \\
5.3. & -0.38 & 0.26 & -0.50 & 0.27 & -1.45 & 0.19 \\
5.4. & 0.36 & 0.20 & 0.36 & 0.74 & 1.79 & 0.11 \\
5.5. & -0.74 & 0.28 & -0.92 & 0.20 & -2.69 & $0.03^{*}$ \\
5.6. & 0.35 & 0.10 & 0.44 & 0.41 & 3.53 & $0.01^{*}$ \\
5.8. & 0.65 & 0.34 & 0.75 & 0.18 & 1.89 & 0.10 \\
7.1. & -0.43 & 0.25 & -0.57 & 0.17 & -1.73 & 0.12 \\
7.2. & 0.14 & 0.10 & 0.22 & 1.00 & 1.36 & 0.21 \\
7.3. & 0.23 & 0.11 & 0.32 & 0.86 & 2.00 & 0.08 \\
7.4. & 0.14 & 0.06 & 0.24 & 0.89 & 2.34 & $0.05^{\star}$ \\
7.5. & 0.01 & 0.11 & 0.01 & 0.62 & 0.05 & 0.96 \\
7.6. & -0.16 & 0.26 & -0.15 & 0.68 & -0.60 & 0.57 \\
7.8. & 0.41 & 0.16 & 0.83 & 0.18 & 2.57 & $0.03^{*}$ \\
7.9. & 0.23 & 0.15 & 0.53 & 0.25 & 1.58 & 0.15 \\
7.10. & 0.15 & 0.06 & 0.28 & 0.92 & 2.54 & $0.03^{*}$ \\
(Intercept) & 1.07 & 0.77 & - & -39 & 1.39 & 0.20 \\
\hline
\end{tabular}

\section{Discussion}

This study confirms some of the previous results from authors worldwide, but also provides new information regarding the Balkan countries and labour market efficiency. The significance of this research is supported by the fact that human resource development and market demands for competences also affect the development of the country's economy. These results may have important implications for labour market efficiency and strategic national labour market framework development. The obtained results also provide more detailed information about the factors that influence human resource competence development, as well as public policy creation. 
The aim of this paper was to introduce recent research on the correlation between two pillars such as Higher education and training and Labour market efficiency for 25 countries. Research findings showed a high positive correlation between variables within pillar 5 , whereas negative correlation has been measured within pillar 7 .

Whereas, according to the results of the regression method, most important factors affecting the score are 5.1. in Secondary education enrollment, 5.2. in Tertiary education enrollment, 5.5. in Quality of management schools, 5.6 in the Internet access, 7.4. in Redundancy costs, weeks of salary, 7.8. in Country capacity to retain talent and 7.10. in Women in labour force, ratio to men. That means that countries with a high score of these indicators have a better score on the Global Competitiveness Index. Focusing on these indicator can thus have significant effects on increasing national economies. The implication of this research can apply to all policy makers, business managers and others who want to improve economic growth.

The results of correlation, as well as regression, implicate the importance of indicators 5.1, 5.2, 5.5, 5.6, 7.4, 7.8, 7.10. If we compare these to the ranks of The Global Competitiveness Report 2015-2016, the most competitive countries such as the top 3 according to the $\mathrm{GCl}$ have the following ranks: Switzerland has the highest rank of indicator, 7.8 in the Country capacity to retain talent, while the USA is in the second position and Singapore occupies the 6th. However, the results of correlation showed that Pillars 5 and 7 have a medium strength which means it is positive, and the variables are changing in the same direction, while the most powerful impact on $\mathrm{GCl}$ is observed between Macroeconomic Environment and Health and primary education.

The results can be important for developing countries that want to improve their economy growth. For that reason, we concentrated on the Higher education and training and Labour market efficiency. Higher education is important for development and has direct effects on Labour market. The quality of higher education is essential for the progress of national economies that strive to have highly-educated young staff with better opportunities for better employment. This pillar measures the quality of education system, science and management in schools, secondary education, tertiary education and quality of training of personnel. Taking into account the reviews of the World Economic Forum, the best ranks for Higher education and training pillar are those of the countries such as Finland, Singapore, the Netherlands, Switzerland, Belgium and Norway (World Economic Forum, 2015).

\section{Conclusion}

One of the strategies, made by policy makers based on the experience of the developed countries, is that the strategy should be useful and professional, and vocational training must be widespread as is the case in Scandinavia. In the Netherlands, training programmes are adjusted to young people so that they can enter the labour market in the easiest way and in the shortest period (Refrigeri and Aleandri, 2013). Countries with a high score of labour market efficiency are aware that workers are allocated to their most effective use in the economy and provided with an incentive to give the best efforts in their jobs. According to the World Economic Forum, 2015, the best five ranking countries for Labour market efficiency are Switzerland, Singapore, Hong Kong, the U.S.A., the U.K. and New Zealand (World Economic Forum, 2016).

In our case, we investigated how important it is for a country to have educated people and how difficult it is to achieve a high rank in labour market efficiency without them. A future study can be the application of the same methodology for the The Global Competitiveness Report 2015-2016 and 2016-2017 among the Balkan countries in comparison with the best 15 countries.

\section{Acknowledgments}

This paper is part of the research project number 179001 financed by the Ministry of Science and Technological Development of the Republic of Serbia.

\section{REFERENCES}

[1] Artto, E.W. (1987). Relative total costs - an approach to competitiveness measurement of industries. Management International Review 27, 1987, 47-58. http://www.jstor.org/sTable/40227838

[2] Bosio, G., \& Leonardi, M. (2010). The impact of Bologna process on graduate labor market: Demand and supply. Giornale degli Economisti, 69(3), 29- 66.

[3] Capello, R. (2007). A forecasting territorial model of regional growth: The MAAST model. Annals of Regional Science, 41(4), 753-787. DOI: 10.1007/500168-007-0146-2.

[4] Carneiro, P., \& Lee, S. (2011). Trends in quality-adjusted skill premia in the United States, 1960-2000. American Economic Review, 106(1), 2309- 2349. DOI: 10.1257/aer.101.6.2309

[5] Cemberci, M., Civelek, M. E., \& Canbolat, N. (2015). The Moderator Effect of Global Competitiveness Index on Dimensions of Logistics Performance Index. Procedia - Social and Behavioral Sciences, 195, 1514-1524. http://doi.org/10.1016/j.sbspro.2015.06.453 
[6] Chevalier, A., \& Lindley, J. (2009). Over education and the skills of UK graduates. Journal of Royal Statistics Society: Series A (Statistics in Society), 2, 307-337. DOI:10.1111/j.1467-985X.2008.00578

[7] Cirstea, D.S. (2014). Travel \& Tourism competitiveness: a study of world's top economic competitive countries. Economics and Finance, 15, 1273-1280. DOI:10.1016/S2212-5671(14)00588-7

[8] Cohen, J., Cohen, P., West, S. G., \& Aiken, L. S. (2013). Applied multiple regression/correlation analysis for the behavioral sciences. Routledge

[9] Constantini, V. \& Monni, S. (2008). Environment, human development and econometric growth. Ecological Economics, 64(2), 867-80. DOI:10.1016/j.ecolecon.2007.05.011

[10] Fagerberg, J. (1996). Technology and competitiveness. Oxford review of Economic Policy, 12(3), 39-51. http://www.jstor.org/sTable/23606440

[11] Fagerberg, J., Srholec, M., \& Knell, M. (2007). The competitiveness of nations: Why some countries prosper while others fall behind. World development, 35(10), 1595-1620. DOI: 10.1016/j.worlddev.2007.01.004

[12] Foss, N. (2005). Strategy, economic organization, and the knowledge economy. The coordination of firms and resources. Oxford and New York: Oxford University Press. ISBN: 0-19-924064-7

[13] Hanushek, E.A. (2013). Economic growth in developing countries: The role of human capital, Economic of Education Review, 37, 204-212. DOI: 10.1016/j.econedurev.2013.04.005

[14] Hazakis, K. (2011). Rethinking the interaction between FDI and competitiveness in West Balkans: an institutionalist approach, International journal of economic policy in emergence economies, 4(2), 36-43.

[15] Holsapple, C. W., \& Singh, M. (2001). The knowledge chain model: activities for competitiveness. Expert systems with applications, 20(1), 77-98. DOI:10.1016/S0957-4174(00)00050-6

[16] International Management Development Institute. (2001). The World Competitiveness Yearbook.

[17] Josserand, E. (2004). The network organization. Cheltenham and Northampton, MA: Edward Elgar. ISBN: 1843765942.

[18] Kazlauskaite, R., \& Buciuniene, I. (2008). The Role of Human Resources and Their Management in the Establishment of Sustainable Competitive Adventage. Engineering Economics, 60(5), 78-84

[19] Lall, S. (2001). Competitiveness Indices and Developing Countries: An Economic Evaluation of the Global Competitiveness Report. World development, 29(9), 1501-1525, Queen Elizabeth House, Oxford, UK. DOI: 10.1016/S0305-750X(01)00051-1

[20] Montfort, P. (2008). Convergence of EU regions: Measures and evolution. Brussels: Publications office of the European Commission, Retrieved from http://citeseerx.ist.psu.edu/viewdoc/download?doi=10.1.1.593.7351\&rep=rep1\&type=pdf

[21] North, M. (2012). Data mining for the Masses. A global text Project Book, ISBN: 0615684378

[22] OECD (2013), Education at a Glance 2013: OECD Indicators, OECD Publishing.

[23] Onsel, D., Ülengin, F., Ulusoy, G., Aktap, E., Kabak, O., \& Topcu, Y. I. (2008). A new perspective on the competitiveness of nations. Socio-Economic Planning Sciences, 42(4), 221-246. DOI:10.1016/J.SEPS.2007.11.001

[24] Pavlovic, D. (2015). Savremeni izazovi u primeni inovativne aktivnosti u sektoru malih i srednjih preduzeca u Srbiji, The Scientific Conference YUPMA, Belgrade, Serbia. ISBN 978-86-7680-320-0

[25] Perez-Moreno, S., Rodríguez, B., \& Luque, M. (2016). Assessing global competitiveness under multicriteria perspective. Economic Modelling, 53, 398-408. http://doi.org/10.1016/j.econmod.2015.10.030

[26] Psacharopoulos, G., \& Patrinos, H.A. (2004). Returns to investment in education: a further update. Education Economics, vol. 12, Issue 2, pp.111-134. DOI: 10.1080/0964529042000239140.

[27] Refrigeri, L., \& Aleandri, G. (2013). Educational policies and youth unemployment. 3th World Conference on Learning, Teaching and Educational Leadership, Social and Behavioural Sciences, 93, 1263-1268. DOI:10.1016/j.sbspro.2013.10.026

[28] Shane, S. \& Venkataraman, S. (2000). The promise of entrepreneurship as a field of research. Academy of Management Review, vol. 25, pp. 217-226. DOI: 10.2307/259271

[29] Spence, M. (1973). Job Market Signaling. The Quarterly Journal of Economics, 87(3), 355-374. DOI:10.1016/B978-0-12-214850-7.50025-5

[30] Tucker, M.S. (2012). The Phoenix: Vocational Education and Training in Singapore. International Comparative Study of Leading Vocational Education System. Center on International Education Benchmarking.

[31] Ucbasaran, D. Wright, M. \& Westhead, P. (2008), Opportunity identification and pursuit does an entrepreneur's human capital metter?, Small Business Economics, vol. 30, pp 153-173. DOI: 10.1007/s11187-006-9020-3

[32] Ulengin, F., Kabak, O., Onsel, S., Aktas, E. \& Parker, B.R. (2011). The Competitiveness of nations and implications for human development. Socio-Economic Planning Sciences, 45(1), 16-27. DOI:10.1016/j.seps.2010.10.001

[33] Walker, I., \& Zhu, Y. (2008). The college wage premium and the expansion of higher education in the UK. Scandinavian Journal of Economics, 110(4), 695-709. DOI: 10.1111/j.1467-9442.2008.00557 
[34] World Economic Forum. (2005). The Global Competitiveness Report 2005, Retrieved from www.weforum.org/reports?filter[type] =Competitiveness

[35] World Economic Forum. (2015). The Global Competitiveness Report 2014 - 2015, retrieved from www.weforum.org/reports?filter[type] =Competitiveness

[36] World Economic Forum. (2016). The Global Competitiveness Report 2015 - 2016, retrieved from www.weforum.org/reports?filter[type] =Competitiveness

[37] Wu, W., Lawrence, W. and Lee, Y. (2012). Critiquing the World Economic Forum's concept of destination competitiveness: A further analysis. Tourism Management Perspective, 4, 198-206. DOI:10.1016/j.tmp.2012.08.008

[38] Zinnes, C., Eilat, Y., \& Sachs, J. (2001). Benchmarking competitiveness in transition economies, Economics of Transition, 9(2), 315-353. DOI: 10.1111/1468-0351.00078

Received: 2017-07-16

Accepted: 2018-07-03

\section{$1 / 1 / 1 / 1 / 1 / 1 / 1 / 1 / 1 / 1 / 1 / 1 / 1 / 1 / 1$ about he eathor}

\section{Dejana Pavlović \\ Institute of Economic Sciences, Belgrade e-mail: dejana.pavlovic@ien.bg.ac.rs}

Dejana Pavlović works as a Research Assistant at the Institute of Economic Sciences in Belgrade. In academic year 2012/2013 she became a candidate for a doctoral degree at the Faculty of Organizational Sciences, with the focus on Management and Informational Systems. She has published more than 25 papers in the field of Strategic management and youth unemployment in Serbia and abroad. Scientific and Research Fields: Strategic Management, HR Management, Labor Economics.

\section{Tijana Obradović \\ University of Belgrade, Faculty of Organizational Sciences, Serbia e-mail: obradovic.tijana@fon.bg.ac.rs}

Tijana Obradović is an Assistant Professor at the University of Belgrade, Faculty of Organizational Sciences, Serbia, where she acquired her Ph.D. (2014) degree in Financial Management. The areas of her research include: Managerial Accounting, Financial Analysis and Performance Management.

\section{Dragan Bjelica University of Belgrade,Faculty of Organizational Sciences, Serbia e-mail: bjelica.dragan@fon.bg.ac.rs}

Dragan Bjelica is an Assistant Professor at the University of Belgrade, Faculty of Organizational Sciences, Serbia, where he acquired his Ph.D. (2017) degree in Project Management. He is a member of several international scientific organizations. In the Serbian Project Management Association, he holds a position of the IPMA Young Crew Serbia chair. Also, he is engaged in the IPMA Young Crew Association programme worldwide as IPMA Young Crew Coach and Mentor. His primary research areas are project management, strategic management and project appraisals. He has published over 60 papers in peer-reviewed conferences and journals and taken part in the implementation of over 10 scientific and commercial projects in the field of management in Serbia and abroad.
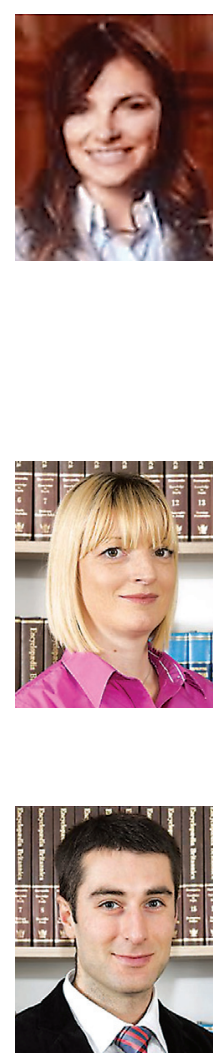

${ }^{1}$ Detail explanation of $\mathrm{GCl}$ is available on the website World Economic Forum

2 The survey questionnaire and the survey forecasts are all available on the website World Economic Forum

${ }^{3}$ The source for indicators p 537-545 of the latest report, The Global Competitiveness Report 2015, and the computation in Appendix B, p. 49-51 